\title{
Changes in the abundance and structure of bacterial communities under long-term fertilization treatments in a peanut monocropping system
}

\author{
Wuxing Liu • Qingling Wang • Baozhan Wang • \\ Xiaobing Wang • Ashley E. Franks • Ying Teng • \\ Zhengao Li • Yongming Luo
}

Received: 28 October 2014 / Accepted: 15 June 2015 / Published online: 4 July 2015

(C) Springer International Publishing Switzerland 2015

\begin{abstract}
Background and aims Peanut yield and quality are seriously compromised by continuous monoculturing in the red soil region of southern China. Monoculturing can cause soil degradation and an increase in soil-borne diseases. This research aimed to investigate the influence of long-term peanut monocropping and different fertilization treatments on peanut growth, soil physical and chemical properties and soil microbial community. Methods A long-term fertilization experiment established in 1996 was utilized to examine the effect of various fertilization treatments including chemical and organic fertilizers treatments. Deep 16S rRNA gene
\end{abstract}

Responsible Editor: John A. Kirkegaard.

Electronic supplementary material The online version of this article (doi:10.1007/s11104-015-2569-3) contains supplementary material, which is available to authorized users.

W. Liu $(\bowtie) \cdot$ Q. Wang $\cdot$ B. Wang $\cdot$ Y. Teng $\cdot$ Z. Li $\cdot$ Y. Luo Key Laboratory of Soil Environment and Pollution Remediation, Institute of Soil Science, Chinese Academy of Sciences, Nanjing 210008, China

e-mail: liuwuxin@issas.ac.cn

X. Wang

College of Environmental Sciences and Engineering,

Yangzhou University, Yangzhou 225009, China

A. E. Franks

Department of Microbiology, La Trobe University,

Melbourne, VIC 3086, Australia

Y. Luo

Institute of Coastal Zone Research, Chinese Academy of

Sciences, Yantai 264003, China pyrosequencing highlighted changes in the abundance and structure of bacterial communities, especially of the pathogenic and beneficial bacterial communities in long term chemical fertilizer treatment in comparison to the organic manure treatment.

Results Chemical fertilizer treatment causes a shift in bacterial community structure and decrease in diversity under the long-term monocropping in comparison to organic fertilizer. The abundance of the bacterial pathogen Ralstonia solanacearum, a causative agent of peanut wilt, was found to be associated with a loss of community diversity and loss of the peanut yield.

Conclusions The organic fertilizers more effectively increase microbial diversity in the soil and changed the community structure. Long-term use of the chemical fertilizer leads to a decrease in microbial diversity of the soil and an increase in $R$. solanacearum with associated increase of peanut wilt. The potential decrease in diversity and competition between the bacterial community and the pathogen may be a contributing factor to increased disease during long-term chemical fertilizer use.

Keywords Peanut monocropping - Chemical fertilizer Organic fertilizer $\cdot$ Bacterial community $\cdot$ Ralstonia solanacearum

\section{Introduction}

Peanut (Arachis hypogaea L.) is the predominant upland crop in the hilly red soil region of southern China (Wang and Chen 2005). The warm climate, sunlight and 
moisture are adequate for production but production is often hindered due to poor fertility and strong acidity of the red soil (Liu and He 1991). Peanut plants have generally been monocropped continuously on a large scale in these regions due to limited arable land and a requirement for intensifying regional agroindustrialization (Lian et al. 2010). Numerous studies have indicated that consecutive monoculturing can lead to crop yield and quality decline and increased disease pressure (Larkin 2003; Li et al. 2012). Wang and Chen (2005) investigated peanut yield change with increasing monocropping years at farm scale and reported that peanut yield in the continuous 10 and 21 years monocropping fields decreased by 28.9 and $51.2 \%$, respectively, compared with the continuous 3 years monocropping field.

Soil microorganisms are vital to agroecosystem function and sustainability but are sensitive to changes in land management practices, such as cropping system, tillage and fertilization (Zhou et al. 2014). Consequently, soil microbial parameters such as microbial composition and diversity have been suggested as possible indicators of soil quality and soil function (Kong et al. 2011). It is reported that crop rotation and organic matter inputs can increase the soil microbial biomass enhancing soil enzymatic activities involved in nutrient transformation which leads to improved soil quality and enhanced soil function (Acosta-Martínez et al. 2010). Reports also indicate that chemical fertilizers which introduce $\mathrm{N}$ (nitrogen), $\mathrm{P}$ (phosphorus), and $\mathrm{K}$ (potassium) can also lead to the increased soil productivity and improve soil microbial properties such as microbial biomass $\mathrm{C}$ and $\mathrm{N}$, and microbial diversity (McAndrew and Malhi 1992; Wu et al. 2011). Improvements to crop yield and soil carbon over the short-term has been reported in some studies investigating the influence of chemical and organic fertilizers applications on soil bacterial diversity and community function (Crecchio et al. 2001; Peacock et al. 2001). In contrast, other studies have also found that most of the microbiological characteristics studied did not differentiate between fertilized and non-fertilized treatments over a longer time period of up to many years (Sarathchandra et al. 2001; Freitag et al. 2005). Studies reporting the microbial communities changes in response to fertilization treatments have mostly been performed by traditional molecular technique such as Denaturing Gradient Gel Electrophoresis (DGGE) (Ribeiro et al. 2013). These studies are often limited due to low resolution taxonomic information provided by DGGE and by limits in the ability of DGGE to detect low abundance bacteria groups present in the soil. This may cause important small-scale community members to be over looked (Chen et al. 2013). Therefore, more advanced techniques are needed to detect key changes in the microbial ecology within the low abundance bacteria groups. In recent years, the next generation pyrosequencing technology has allowed 16S rRNA gene sequencing, at a high throughput and low cost, more indepth microbial community diversity investigations (Das and Kazy 2014).

Soil-borne diseases have become a prevalent problem in the production of many annual crops subject to intensive monocropping (Li et al. 2014a). To date, many studies concentrated on fungi as a causative agent of for the crop productivity decline. Li et al. (2014b) reported that the fungal pathogens, such as Leptosphaerulina sp., Fusarium sp., were the dominant fungal pathogens responsible for peanut disease and yield declines over the consecutive peanut monocultures. However, peanut sickness and decline caused by bacterial pathogens has not been studied in this red soil region. Our previous study showed peanut bacterial wilt caused by Ralstonia solanacearum tended to increase in prevalence with increasing monocropping years (Wang et al. 2011). Peanut wilt is a soil-borne bacterial pathogen notorious for its lethality, persistence, complex subspecies, wide host range, and broad geographic distribution (Allen et al. 2005). Nevertheless, the bacterial community structure and diversity shifts under the different longterm fertilization were rarely studied by the method of pyrosequencing and an interaction with $R$. solanacearum has not been detected.

This research aimed to investigate the influence of long-term peanut monocropping and different application of fertilizer on peanut growth, soil physical and chemical properties and soil microbial community. To achieve this aim agricultural soil samples from the red soil region of southern China that had been subject to either: 2 years of peanut monocropping using chemical fertilizer (S-CF) (Previously planted with kiwi fruit prior to peanut monocropping treatment); long-term (16 years) of continuous monocropping with chemical fertilizer (L-CF) or; long-term (16 years) of continuous monocropping with organic manure amendments (L$\mathrm{OM})$. Soil analysis and deep sequencing revealed the relationship of different fertilization regimes with pathogens incidence, offering useful information for 
bacterial wilt disease suppressive and better guidance to peanut cropping.

\section{Material and methods}

Description of the experimental site and sampling

The long-term field fertilizer experiment of peanut (Ganhua 5) continuous monocropping was initiated in 1996 at Ecological Experimental Station of Red Soil, Chinese Academy of Sciences, Yingtan, southern Jiangxi Province of China $\left(116^{\circ} 55^{\prime} \mathrm{E}, 28^{\circ} 12^{\prime} \mathrm{N}\right)$. The region has a typical subtropical monsoon climate with an annual precipitation of $1795 \mathrm{~mm}$, annual evaporation of $1318 \mathrm{~mm}$ and a mean annual temperature of $17.6^{\circ} \mathrm{C}$, with an average of 262 frost-free days. The tested soil was classified as a Haplic Stangnic Anthrosol and derived from quaternary red clay. Soil samples $(0-20 \mathrm{~cm})$ taken from experimental site in April 1996 at the beginning of the experiment contained $0.6 \mathrm{~g} \mathrm{~kg}^{-1}$ total $\mathrm{N}$, $0.2 \mathrm{~g} \mathrm{~kg}^{-1}$ total $\mathrm{P}, 14.5 \mathrm{~g} \mathrm{~kg}^{-1}$ total $\mathrm{K}, 43.3 \mathrm{mg} \mathrm{kg}^{-1}$ hydrolysable $\mathrm{N}$, undetectable available $\mathrm{P}\left(\mathrm{NaHCO}_{3}\right.$-extractable $\mathrm{P})$ and $84 \mathrm{mg} \mathrm{kg}^{-1}$ available $\mathrm{K}\left(\mathrm{NH}_{4} \mathrm{OAc}-\right.$ extractable $\mathrm{K}), 8.4 \mathrm{~g} \mathrm{~kg}^{-1}$ organic matter (OM) and had a $\mathrm{pH}$ of 3.90 (Table 1). The 2 years of peanut monocropping with chemical fertilizers (S-CF) was also conducted at the same site and initiated in 2010.

\section{Fertilization treatments}

Peanut (Ganhua 5) was sowed manually on April 10th of each year by placing two seeds per hole to give a $10 \mathrm{~cm}$ plant-to-plant spacing and $30 \mathrm{~cm}$ row-to-row spacing. The plot site was used for either 16 years of continuous peanut monocropping or 2 years of peanut monocropping. Plots received one of 3 treatments: (L$\mathrm{CF}$ ) long-term (16 years) of peanut monocropping with chemical fertilizer of $\mathrm{N}, \mathrm{P}, \mathrm{K}$ at 45,45 , and $135 \mathrm{~kg} \mathrm{ha}^{-1}$, respectively; (L-OM) long-term (16 years) of peanut monocropping with organic fertilizer (pig manure); and (S-CF) 2 years of peanut monocropping with chemical fertilizer of $\mathrm{N}, \mathrm{P}, \mathrm{K}$ at the same rate as the L-CF treatment. The treatments were arranged in a randomized complete block design with four replicates. Each plot was $5.5 \times 6.0 \mathrm{~m}$ with a concrete wall embedded $20 \mathrm{~cm}$ into soil between each plot. N, P and K were supplied as urea, calcium magnesium phosphate and potassium chloride in treatment L-CF and S-CF, respectively. Pig manure in treatment L-OM was bought after fermenting from a nearby pig farm every year and $1 \mathrm{~kg}$ air-dried pig manure sample was collected at the time of application to determine its components. Pig manure was added at the rate of $1.69 \mathrm{tha}^{-1}$ (dry weight). The average composition of the pig manure was $\mathrm{pH} 8.5$, OM 602, N, P, K 26.7, 18.3 and $53.1 \mathrm{~g} \mathrm{~kg}^{-1}$, respectively. $14 \mathrm{~kg} \mathrm{P} \mathrm{ha}{ }^{-1}$ of calcium magnesium phosphate and $45 \mathrm{~kg} \mathrm{~K} \mathrm{ha}^{-1}$ of potassium chloride was added to the L-OM treatment to attach the equal final rates of total $\mathrm{N}$, $\mathrm{P}, \mathrm{K}$ to the L-CF treatment $\left(45,45\right.$, and $135 \mathrm{~kg} \mathrm{ha}^{-1}$, respectively). All of fertilizer was applied to the surface of the soil as base fertilizer 1 day before sowing peanut. Soil characteristics analysis and quality analysis of peanut kernel

Soil sampling was conducted in sowing season (April), flowering season (June), and harvest season (August) in 2012. Five soil cores $(0-20 \mathrm{~cm})$ of bulk soil were taken randomly across each plot from the root zone in each replication. The soil was then mixed and homogenized by passing through $<2 \mathrm{~mm}$ sieve to remove aboveground plant materials, roots, and stones and stored at $-70{ }^{\circ} \mathrm{C}$ prior to soil DNA extraction and at $4{ }^{\circ} \mathrm{C}$ for other analyses. Selected characteristics of the soil samples are listed in Table 1. Soil samples taken from the experimental area in 2012 were analyzed. Chemical properties of: $\mathrm{pH}$; OM; total N, P, K; hydrolysable $\mathrm{N}$; and available $\mathrm{P}, \mathrm{K}$ in the soil samples were determined using routine methods ( $\mathrm{Lu} \mathrm{1999).}$

Peanut plants were harvested manually in August and all harvested biomass was removed from the plots. Yields were determined by removing peanut plants, air-drying in the field for 4-6 d on concrete, threshing and oven drying at $65{ }^{\circ} \mathrm{C}$ to a constant moisture level, and then weighing.

\section{Soil DNA extraction and PCR}

DNA was isolated from $0.5 \mathrm{~g}$ of mixed soil using the FastDNA Kit (Qbiogene Inc., CA, USA) and purified on agarose gels (Moreira 1998). The primer pair $515 \mathrm{f}$ and 907r (515F 5'- GTGCCAGCMGCCGCGG-3', 907R 5'- CCGTCAATTCMTTTRAGTTT-3') were utilized to amplify a 392 base pair fragment of the $16 \mathrm{~S}$ rRNA gene for 454 pyrosequencing (Xu et al. 2013).

An aliquot of $1 \mathrm{uL}$ DNA was used in the PCR reaction. The PCR conditions used for amplification were $94{ }^{\circ} \mathrm{C}$ for $2 \mathrm{~min}, 20$ cycles of $94^{\circ} \mathrm{C}, 45 \mathrm{~s}$ denaturation; $55{ }^{\circ} \mathrm{C}, 45 \mathrm{~s}$ annealing and $72{ }^{\circ} \mathrm{C}, 1 \mathrm{~min}$ extension; 
Table 1 Soil properties under different fertilization management and sampling time

\begin{tabular}{|c|c|c|c|c|c|c|c|c|}
\hline Treatments ${ }^{\mathrm{a})}$ & $\mathrm{pH}$ & $\begin{array}{l}\text { Organic Matter } \\
(\mathrm{OM}) \mathrm{g} \mathrm{kg}^{-1}\end{array}$ & $\begin{array}{l}\text { Total N } \\
\mathrm{g} \mathrm{kg}^{-1}\end{array}$ & $\begin{array}{l}\text { Total P } \\
\mathrm{g} \mathrm{kg}^{-1}\end{array}$ & $\begin{array}{l}\text { Total K } \\
\mathrm{g} \mathrm{kg}^{-1}\end{array}$ & $\begin{array}{l}\text { Hydrolysable } \\
\mathrm{N} \\
\mathrm{mg} \mathrm{kg}^{-1}\end{array}$ & $\begin{array}{l}\text { Available P } \\
\mathrm{mg} \mathrm{kg}^{-1}\end{array}$ & $\begin{array}{l}\text { Available } \\
\mathrm{K} \\
\mathrm{mg} \mathrm{kg}^{-1}\end{array}$ \\
\hline $\begin{array}{c}\text { Initial soil } \\
\text { (1996) }\end{array}$ & $3.90 \pm 0.03 \mathrm{~d}$ & $8.4 \pm 0.6 \mathrm{~d}$ & $0.60 \pm 0.08 \mathrm{~d}$ & $0.20 \pm 0.01 \mathrm{~g}$ & $14.5 \pm 0.4 \mathrm{a}$ & $43.3 \pm 3.9 \mathrm{e}$ & - & $84 \pm 7$ e \\
\hline $1 \mathrm{~S}-\mathrm{CF}$ & $4.10 \pm 0.04 \mathrm{~d}$ & $6.9 \pm 0.8 \mathrm{~d}$ & $0.47 \pm 0.09 \mathrm{e}$ & $0.25 \pm 0.04 \mathrm{f}$ & $10.7 \pm 0.6 \mathrm{e}$ & $44.2 \pm 6.7 \mathrm{e}$ & $4.1 \pm 0.4 \mathrm{~d}$ & $83 \pm 5 \mathrm{e}$ \\
\hline $1 \mathrm{~L}-\mathrm{CF}$ & $5.14 \pm 0.15 b c$ & $13.5 \pm 0.5 \mathrm{c}$ & $0.80 \pm 0.03 \mathrm{c}$ & $0.37 \pm 0.02 \mathrm{de}$ & $12.2 \pm 0.4 \mathrm{~cd}$ & $56.9 \pm 8.6 \mathrm{~cd}$ & $5.6 \pm 0.2 \mathrm{~d}$ & $292 \pm 25 \mathrm{~d}$ \\
\hline 1L-OM & $6.41 \pm 0.21 \mathrm{a}$ & $15.2 \pm 0.3 \mathrm{~b}$ & $0.96 \pm 0.05 \mathrm{~b}$ & $0.97 \pm 0.06 \mathrm{ab}$ & $13.7 \pm 0.1 \mathrm{~b}$ & $60.4 \pm 0.4 \mathrm{bcd}$ & $126.4 \pm 5.6 \mathrm{a}$ & $454 \pm 48 \mathrm{c}$ \\
\hline $2 \mathrm{~S}-\mathrm{CF}$ & $4.08 \pm 0.06 \mathrm{~d}$ & $7.1 \pm 0.8 \mathrm{~d}$ & $0.47 \pm 0.02 \mathrm{e}$ & $0.30 \pm 0.06$ ef & $11.8 \pm 0.1 \mathrm{~cd}$ & $53.5 \pm 1.3 \mathrm{~d}$ & $4.9 \pm 0.9 \mathrm{~d}$ & $98 \pm 13 \mathrm{e}$ \\
\hline 2L-CF & $4.97 \pm 0.17 \mathrm{c}$ & $12.7 \pm 1.4 \mathrm{c}$ & $0.82 \pm 0.03 \mathrm{c}$ & $0.39 \pm 0.02 \mathrm{~cd}$ & $12.6 \pm 0.4 \mathrm{c}$ & $60.5 \pm 6.8 \mathrm{bcd}$ & $7.0 \pm 0.7 \mathrm{~d}$ & $346 \pm 34 d$ \\
\hline 2L-OM & $6.46 \pm 0.06 \mathrm{a}$ & $15.9 \pm 0.8 \mathrm{~b}$ & $0.97 \pm 0.02 \mathrm{~b}$ & $1.01 \pm 0.06 \mathrm{a}$ & $14.7 \pm 0.1 \mathrm{a}$ & $63.5 \pm 1.2 \mathrm{abc}$ & $97.9 \pm 9.0 \mathrm{~b}$ & $529 \pm 50 \mathrm{a}$ \\
\hline $3 \mathrm{~S}-\mathrm{CF}$ & $4.13 \pm 0.11 \mathrm{~d}$ & $8.1 \pm 1.2 \mathrm{~d}$ & $0.58 \pm 0.04 \mathrm{~d}$ & $0.42 \pm 0.03 \mathrm{~cd}$ & $10.7 \pm 0.9 \mathrm{e}$ & $58.9 \pm 3.7 \mathrm{~cd}$ & $4.4 \pm 0.3 \mathrm{~d}$ & $114 \pm 14 \mathrm{e}$ \\
\hline 3L-CF & $5.28 \pm 0.14 \mathrm{~b}$ & $15.6 \pm 0.8 \mathrm{~b}$ & $0.91 \pm 0.04 \mathrm{~b}$ & $0.45 \pm 0.04 \mathrm{c}$ & $10.9 \pm 0.5 \mathrm{e}$ & $66.9 \pm 5.2 \mathrm{ab}$ & $4.9 \pm 0.8 \mathrm{~d}$ & $514 \pm 51 \mathrm{bc}$ \\
\hline 3L-OM & $6.63 \pm 0.11 \mathrm{a}$ & $18.1 \pm 1.2 \mathrm{a}$ & $1.08 \pm 0.04 \mathrm{a}$ & $0.92 \pm 0.03 \mathrm{~b}$ & $11.7 \pm 0.9 \mathrm{~d}$ & $71.9 \pm 3.7 \mathrm{a}$ & $59.0 \pm 1.3 \mathrm{c}$ & $644 \pm 54 \mathrm{a}$ \\
\hline
\end{tabular}

${ }^{\text {a) }} \mathrm{S}-\mathrm{CF}, 2$ years of peanut monocropping with chemical fertilizer; L-CF, long-term (16 years) of peanut continuous monocropping with chemical fertilizer; L-OM, long-term (16 years) of peanut continuous monocropping with organic fertilizer. The numbers 1, 2, 3 represent different sampling times (April, June and August) in 2012, respectively

Statistical significance was set at a level of $p<0.05$ using Duncan's multiple range tests. The same letter in table represents no significant difference. Values are means \pm standard errors $(n=4)$

followed by $72{ }^{\circ} \mathrm{C}, 6 \mathrm{~min}$. After 20 rounds of amplification, a further three rounds of amplification added the $\mathrm{A}$ and $\mathrm{B}$ adapters to specific ends of the amplified $16 \mathrm{~S}$ rRNA fragment (Margulies et al. 2005). Sequencing was conducted by Majorbio Bio-pharm Technology Co., Ltd (Shanghai, China).

\section{Processing of pyrosequencing data}

The 16S rRNA gene sequence data was analyzed by the pyrosequencing pipeline tools available from the Ribosomal Database Project (RDP) and MOTHUR version 1.24.1 (Schloss et al. 2011). The counts of the number of the sequences of each cluster within each sample were converted to frequencies by dividing the number of counts of each cluster by total number of sequences generated within each sample. The 16S rRNA sequences were first trimmed and then sequences with $<200$ bases were removed from the data sets with MOTHUR. The total number of sequences in each library ranged from $6978 \pm 602$ to $9226 \pm 1232$ among the treatments. Sequences were submitted to the RDP aligner tool for species identification. Further processing analyses was then carried out using the MOTHUR v.1.24.1. The resulting clusters were assessed at $97 \%$ dissimilarity to provide the data needed for diversity analysis. Richness estimators (Chao and Ace) for sample size of 6000 sequence and diversity indices (Shannon and Simpson) were calculated using the MOTHUR program at the cutoff of $97 \%$ (Colwell 2009).

Statistics and data analysis

Statistical analysis was carried out with the software package SPSS 19.0 software. Duncan's multiple range tests were used to compare the means of treatments. Variability in the data was expressed as the standard errors. Differences at $p<0.05$ were considered statistically significant. Bacterial community structure based on all sequences was performed by principal coordinates analysis (PCoA) conducted in R (Version 3.1.2) was used to depict differences in composition and structure of the bacterial communities among the three treatments. Canonical corresponding analysis (CCA), performed on the sequences of 16S r RNA of the likely five associated pathogenic and beneficial bacterial, was used to analyze the relationship between the related 
associated pathogenic and beneficial bacterial sequence patterns and treatments with environmental variables in three treatments at the harvest time (August).

\section{Results}

Effect of consecutive cropping and fertilization on peanut yield, height and soil properties

Peanut kernel yield and height in upland red soil from 1996 to 2012 are presented in Fig. 1. The continuation of continuous cropping with organic matter (L-OM) consistently produced more peanut kernel yield and plant height than in L-CF but both showed yield and height declines over 16 years. The peanut yield and height in L-OM treatment group decreased from $3424 \mathrm{~kg} \mathrm{hm}^{-2}$ and $54.0 \mathrm{~cm}$ in 1996 to $678 \mathrm{~kg} \mathrm{hm}^{-2}$ and $36.3 \mathrm{~cm}$ in 2012 while L-CF decreased from $2876 \mathrm{~kg} \mathrm{hm}^{-2}$ and $36.0 \mathrm{~cm}$ in 1996 to $307 \mathrm{~kg} \mathrm{hm}^{-2}$ and $29.6 \mathrm{~cm}$ in 2012 . The peanut height increased slightly in 1999 by the influence of climate, but presented a downward trend overall the long-term fertilization experiment. The S-CF treatment produced a peanut kernel and height of $2218 \mathrm{~kg} \mathrm{hm}^{-2}$ and $41.8 \mathrm{~cm}$ in 2012 . Soil properties (Table 1) indicated that the soil $\mathrm{pH}$ in L-CF (5.14) and L-OM (6.41) treatments were higher than S-CF treatment (4.10) at the sowing time in 2012. While there was a trend in an increase of $\mathrm{pH}$ in all soil samples from the original soil sampled in 1996 ( $\mathrm{pH} 3.90)$, none of the treatments produced a significant difference between sowing and harvest within a single year. The partial neutralization of soil acidity in L-OM and L-CF treatments compared to the S-CF is likely due to the pig manure or calcium magnesium phosphate in the chemical fertilizer application over a long period (1996-2012). Continuous cropping over a 16 years period had seen an increase in organic matter from $8.4 \mathrm{~g} \mathrm{~kg}^{-1}$ in the original 1996 samples at the start of the long term monoculturing to $13.5 \mathrm{~g} \mathrm{~kg}^{-1}$ (L-CF) and $15.2 \mathrm{~g}$ $\mathrm{kg}^{-1}$ (L-OM) in the final year (2012) (Table 1) Additionally, soil $\mathrm{N}, \mathrm{P}$ and $\mathrm{K}$ contents in all treatments significantly increased after 16 years of cropping and fertilization. Moreover, soil OM, N, P and K were all higher in pig manure treatments than in chemical fertilizer treatments, showing that application of organic manure played a more important role in enhancing soil fertility.

\section{S rRNA pyrosequencing}

The 16S rRNA gene survey produced a total of 182,870 sequence reads with a length between $250 \sim 550 \mathrm{bp}$ from 36 samples. An average of $5946 \pm 480,4675 \pm 548$ and $5619 \pm 750$ (mean \pm SD) bacterial sequences were obtained from the soil samples of the S-CF, L-CF and L$\mathrm{OM}$ treatments at the sowing time, respectively. The structure of the microbial communities in the soil samples from the three peanut treatments at the three sampling times were compared at the level of phylum level (Fig. 2). Overall, about $80-90 \%$ of all reads obtained could be assigned to phylotypes, with approximately $10-20 \%$ of the reads in each sample remaining unclassified. Both species richness and diversity indices of the
Fig. 1 Effect of long-term chemical or organic fertilizers on peanut height and kernel yield in upland red soil from 1996 to 2012. Error bars indicate standard deviation (SD) $(n=4)$

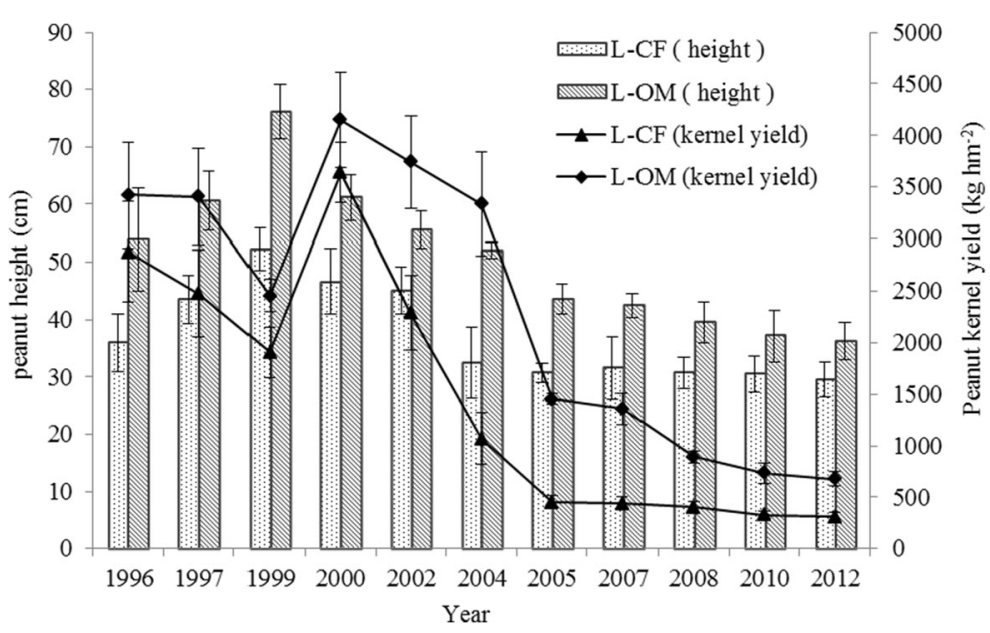


S-CF treatment and L-CF treatment increased in flowering time (June) and then decreased in harvest time (August), while kept rising with the peanut growth in the L-OM treatment despite of no significant difference being observed (Table 2). The order of the ACE (species richness) index changed from sowing time (S-CF $>$ L$\mathrm{OM}>\mathrm{L}-\mathrm{CF}$ ) to harvest $(\mathrm{L}-\mathrm{OM}>\mathrm{S}-\mathrm{CF}>\mathrm{L}-\mathrm{CF})$. Other richness estimators (Chao) and diversity indices (Shannon and Simpson) corroborate this trend (Table 2).

Effect of different long-term fertilizer management of peanut on bacterial community composition

The structures of the overall bacterial communities in the soil samples from the three peanut treatments at the three sampling times were compared at the phylum level (Fig. 2). The results revealed that long-term fertilization regimes resulted in the changes of soil bacterial community structure in the red soil. The relative abundance of Actinobacteria increased from sowing to flowering for L-CF and L-OM treatments, and then declined at harvest, yet Bacteroidetes and Nitrospirae increased across all the growth periods. The bacterial community composition of the organic manure treatment was consistently different to the two chemical fertilizer treatments particularly for the beneficial phylum Nitrospira that was more abundant in the organic matter treatment. Acidobacteria was found to be negatively correct with pH value (Mannisto et al. 2007; Lauber et al. 2008; Fierer 2009). Here, perhaps due to the higher $\mathrm{pH}$, the relative abundance of Acidobacteria was always lower in the L-OM treatment compare with other treatments. In August, the relative abundance of soil-borne pathogen Ralstonia sp. achieved 0.16, 0.48, and $0.28 \%$, compared to $0.04,0.03$, and $0.01 \%$ in April, in the SCF, L-CF and L-OM treatments, respectively (Fig. 4). Ralstonia sp. was always higher in the L-CF treatment than in the L-OM treatment (Fig. 3). The field investigation and observation on incidence rate of peanut bacterial wilt caused by Ralstonia sp. also showed that the ratio of peanut wilt is only $8 \%$ in S-CF treatment, while the ratio of peanut wilt were 58 and $22 \%$ in L-CF and LOM treatments, respectively. At the same time, the abundances of some beneficial bacterial such as Streptomyces sp., Sphingomonas sp., Bacillus sp. and Arthrobacter sp. increased significantly in the three treatments at the different sampling times (Fig. 4).

Principal coordinates analysis clearly showed that the first principal component differentiated the two long-term treatments with L-OM on the positive side of the $\mathrm{x}$-axis and L-CF on the negative side, suggesting large differences in the

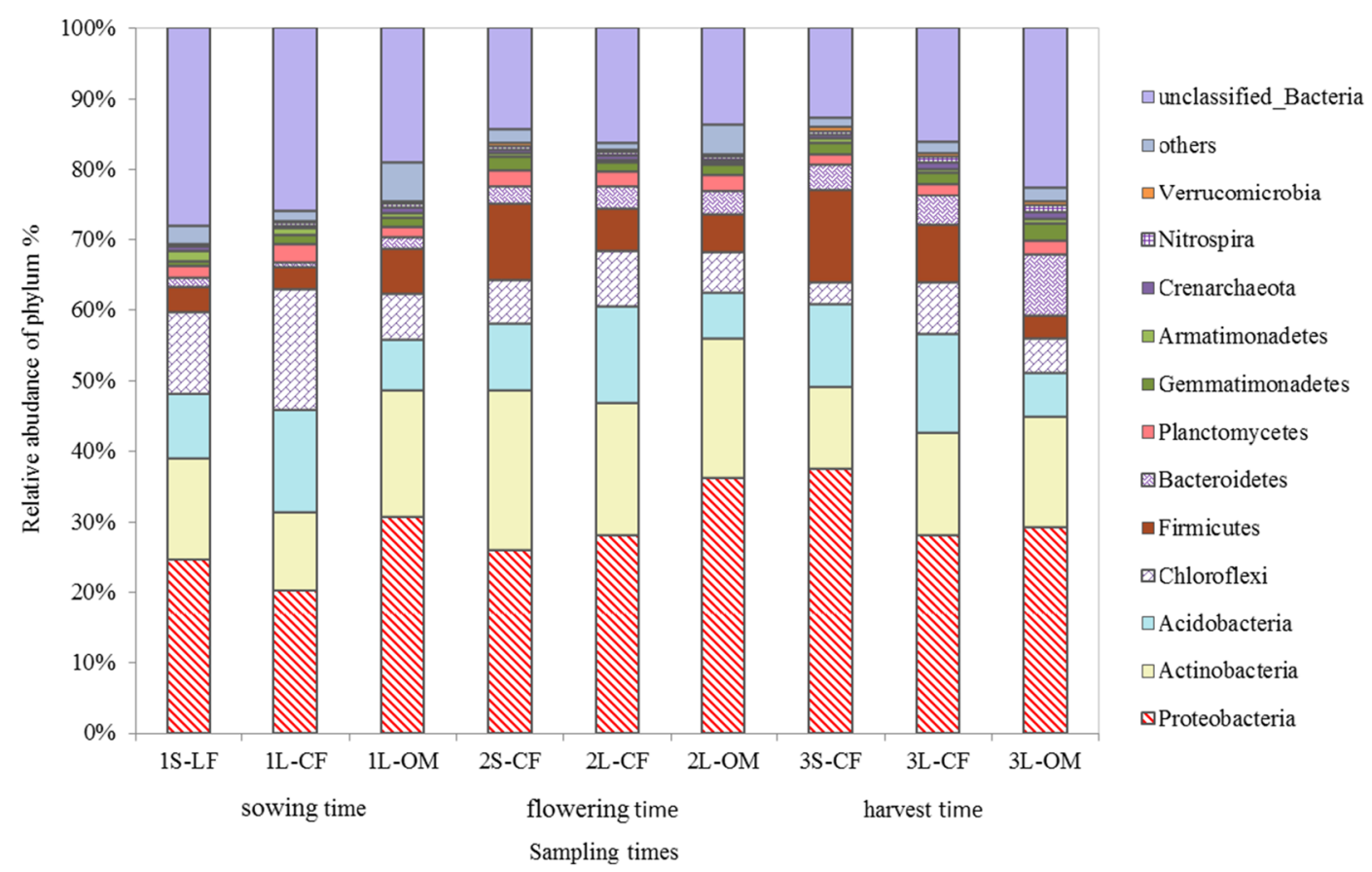

Fig. 2 The frequencies of sequences over phylum level as affected in the soil of the treatments S-CF, L-CF, and L-OM at three stages of peanut development. All of the samples were collected in 2012. The numbers 1, 2, 3 represent as above 
Table 2 Richness estimators and diversity indices ${ }^{\text {a) }}$ of soil bacterial community of the experiment groups with the process of treatment

\begin{tabular}{|c|c|c|c|c|}
\hline \multirow[t]{2}{*}{ Treatments } & \multicolumn{2}{|c|}{ Richness estimators } & \multicolumn{2}{|l|}{ Diversity indices } \\
\hline & $\mathrm{ACE}$ & Chao & Shannon & Simpson \\
\hline $1 \mathrm{~S}-\mathrm{CF}$ & $5946 \pm 480 \mathrm{c}$ & $4161 \pm 396 \mathrm{~cd}$ & $6.54 \pm 0.46 \mathrm{bcd}$ & $0.0068 \pm 0.0002 \mathrm{de}$ \\
\hline 1L-CF & $4675 \pm 548 \mathrm{~d}$ & $3461 \pm 335 d$ & $6.23 \pm 0.27 \mathrm{~d}$ & $0.0051 \pm 0.0004 \mathrm{e}$ \\
\hline 1L-OM & $5619 \pm 750 \mathrm{c}$ & $4148 \pm 336 \mathrm{~cd}$ & $6.48 \pm 0.25 \mathrm{~cd}$ & $0.0062 \pm 0.0002 \mathrm{~d}$ \\
\hline $2 \mathrm{~S}-\mathrm{CF}$ & $7956 \pm 447 \mathrm{ab}$ & $5159 \pm 478 \mathrm{ab}$ & $6.93 \pm 0.23 \mathrm{abcw}$ & $0.0088 \pm 0.0005 \mathrm{c}$ \\
\hline $2 \mathrm{~L}-\mathrm{CF}$ & $7279 \pm 551 \mathrm{~b}$ & $4331 \pm 761 \mathrm{bcd}$ & $6.99 \pm 0.24 \mathrm{abc}$ & $0.0036 \pm 0.0001 \mathrm{f}$ \\
\hline 2L-OM & $8046 \pm 648 \mathrm{ab}$ & $5142 \pm 733 \mathrm{abc}$ & $6.90 \pm 0.45 \mathrm{abc}$ & $0.0170 \pm 0.0017 \mathrm{a}$ \\
\hline $3 \mathrm{~S}-\mathrm{CF}$ & $7581 \pm 273 b$ & $5097 \pm 213 a b c$ & $7.05 \pm 0.14 \mathrm{ab}$ & $0.0090 \pm 0.0007 \mathrm{c}$ \\
\hline $3 \mathrm{~L}-\mathrm{CF}$ & $6097 \pm 396 \mathrm{c}$ & $4326 \pm 160 \mathrm{bcd}$ & $6.84 \pm 0.13 a b c$ & $0.0038 \pm 0.0003 \mathrm{f}$ \\
\hline 3L-OM & $8800 \pm 688 \mathrm{a}$ & $5763 \pm 796 \mathrm{a}$ & $7.21 \pm 0.24 \mathrm{a}$ & $0.0121 \pm 0.0001 \mathrm{~b}$ \\
\hline
\end{tabular}

a) The richness estimators and diversity indices were calculated based on equal number of sequences ( 6000 sequences). The numbers $1,2,3$ represent as above

Statistical significance was set at a level of $p<0.05$ using Duncan's multiple range tests. The same letter in table represents no significant difference. Values are means \pm standard errors $(n=4)$

bacterial community composition of these two treatments $(56.6 \%$ variation on the $\mathrm{x}$-axis). The two chemical fertilization treatments (L-CF and SCF) cluster separately, though both groups are on the negative side of the $\mathrm{x}$-axis. It indicated that organic matter fertilization was a dominant factor influencing the bacterial community composition. The second principal component axis accounted for $20.2 \%$ of the variation amongst samples and clear separation can be seen on this axis between the S-CF and the L-CF and L-OM. This separation most likely reflects that long-term fertilization ameliorated the soil physicochemical properties, thus lead to greater impact on the bacterial community than that in the short time S-CF (Fig. 5). Similar clusters were found on the different treatments at the sowing (Fig. S1) and flowering season (Fig. S2).

Canonical correspondence analysis (CCA) was used to reveal what environmental factors shifted bacterial assemblages in soils. CCA related the changing pattern of bacterial genus and different treatments to different environmental variables such as $\mathrm{pH}$ value, total $\mathrm{N}(\mathrm{TN}), \mathrm{P}$ (TP), and $\mathrm{K}$ (TK) contents, and hydrolysable $\mathrm{N}(\mathrm{HN})$, available P (AP), available K (AK) contents (Fig. 6). Statistical analysis showed that soil properties observed for L-OM could be distinguished from S-CF and
Fig. 3 Relative abundances of Ralstonia sp. pathogen at the genus level, in three treatments (S-CF, L-CF, L-OM) at the three stages of peanut development. Error bars indicate standard deviation (SD) $(n=4)$. Different letters above bars denote statistical significance at $p<0.05$, according to Duncan's tests

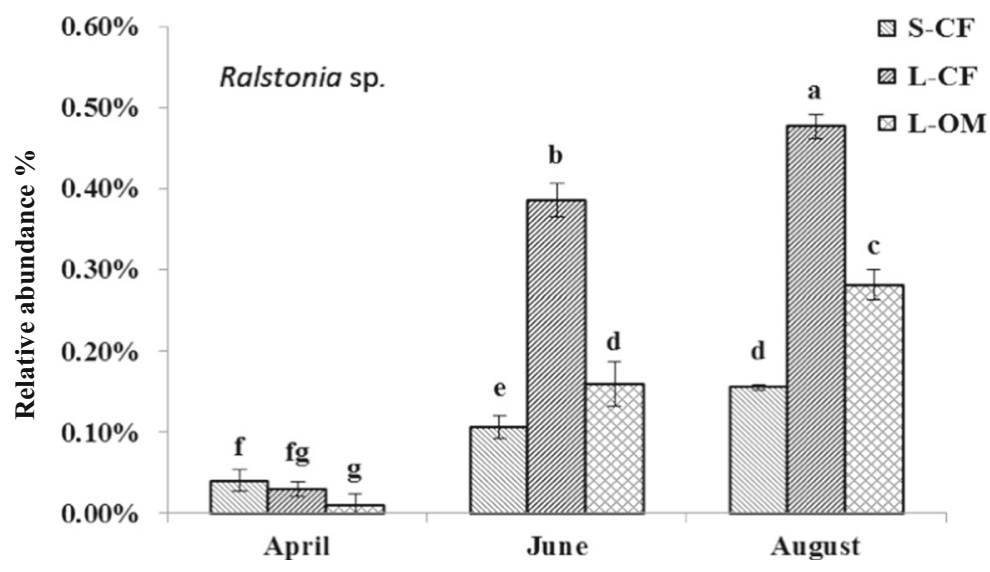



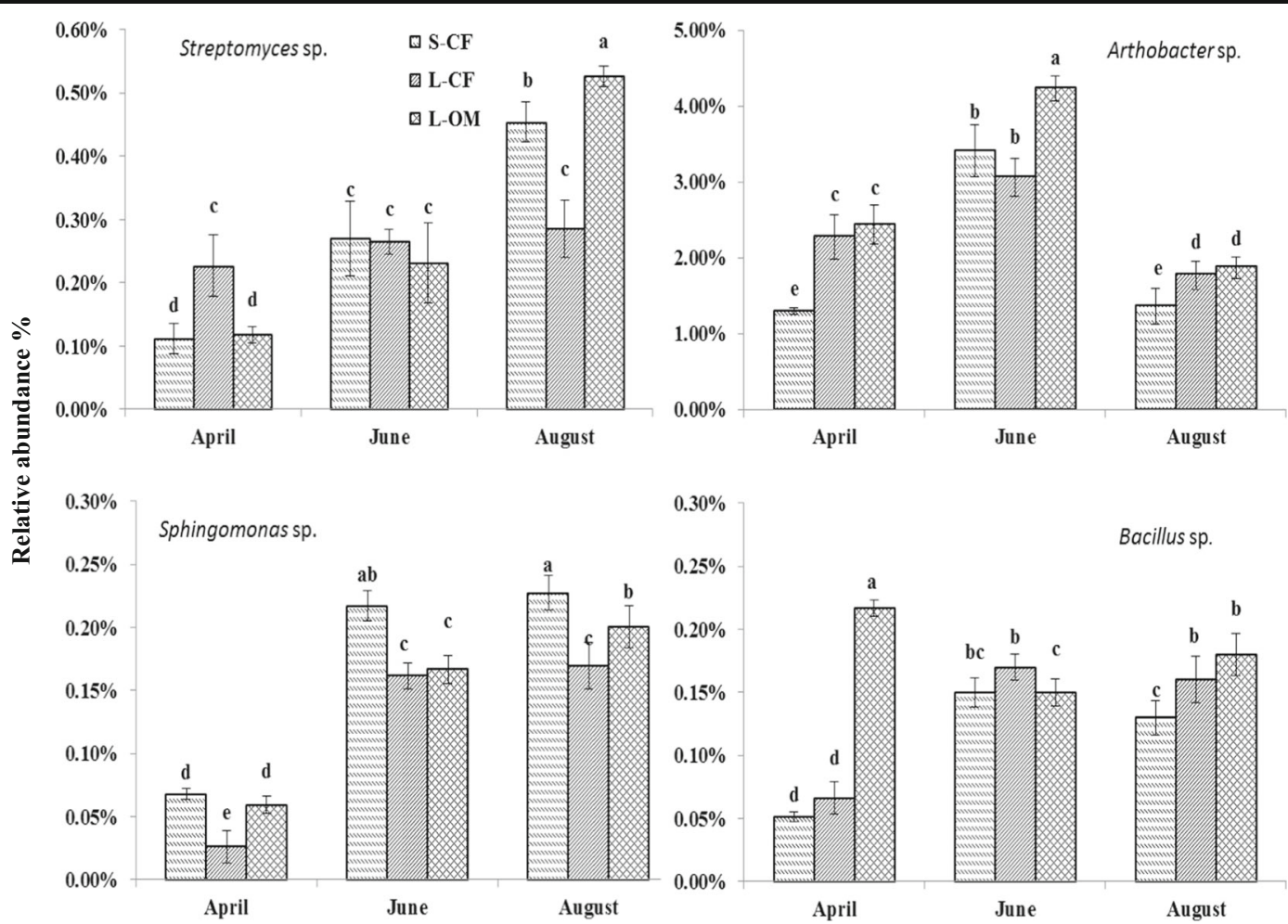

Fig. 4 Relative abundances of four groups of plant beneficial strains at the genus level, Streptomyces sp., Arthobacter sp., Sphingomonas sp., and Bacillus sp. in three treatments (S-CF, L-CF, L-OM) at the three stages of peanut development. Error

bars indicate standard deviation (SD) $(n=4)$. Different letters above bars denote statistical significance at $p<0.05$, according to Duncan's tests

L-CF treatments, which indicated that long-term organic fertilization was more helpful to increase soil fertility and stimulate the growth. Due to the acidic property of the investigated soil, the longterm fertilizations increased soil $\mathrm{pH}$ value. For the associated pathogenic and beneficial bacterial

community genus, CCA further revealed that organic fertilization (L-OM) increased numbers of beneficial bacterial, such as Arthrobacter, Bacillus and Sphingomonas species. In contrast, chemical fertilization (L-CF) increased numbers of pathogenic bacterial, Ralstonia.
Fig. 5 Comparison of bacterial 16S rRNA communities by different treatments was shown using principle coordination analysis (PCoA) based on the total genera (August). The percentages in parentheses indicate the proportions of variation by each ordination axis. The numbers 1, 2, 3, 4 represent four replicates of each treatment, respectively

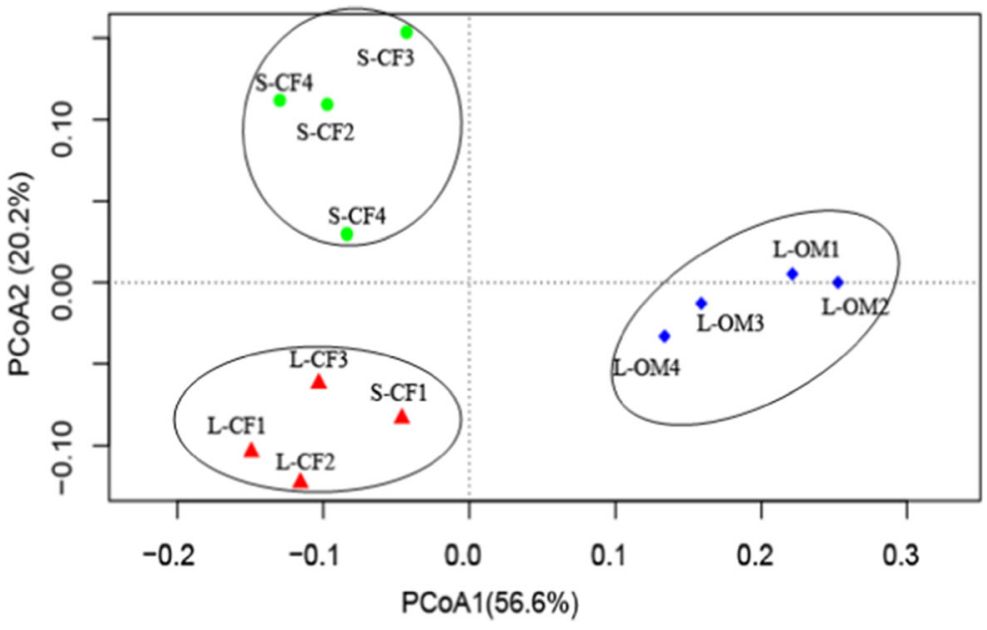


Fig. 6 Canonical correspondence analysis (CCA) relating soils' five associated pathogenic and beneficial bacterial sequence patterns and treatments with environmental variables in 3 different fertilizations treatments at the harvest time (August)

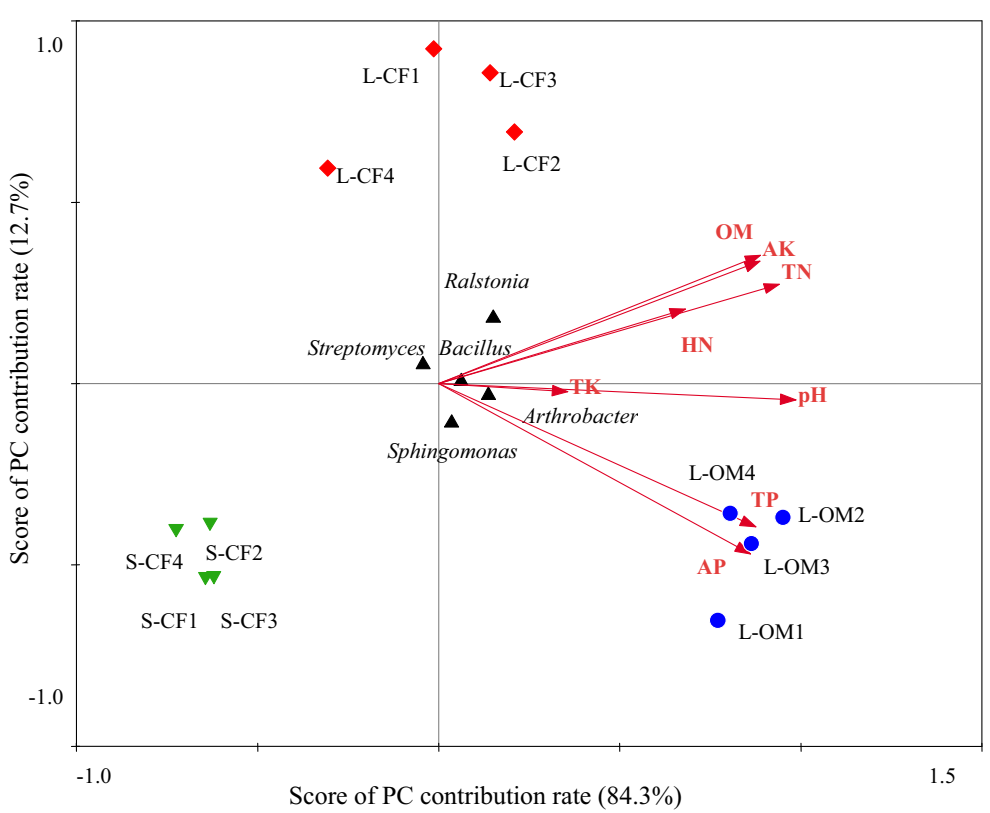

\section{Discussion}

Continuous declines in crop yield and quality caused by the continuous monocropping has caught widespread attention (Nishio and Kusano 1973; Liu et al. 2008; Nie et al. 2008). In our study, the peanut yield and height significantly declined when grown in soil that had been continuously cropped for 16 years with annual fertilization from either chemical fertilizers or organic manure (Fig. 1) compared to soil that had received only 2 years of peanut monocropping (S-CF) treatment (data not shown). Observations during our trials found that peanut bacterial wilt, caused by $R$. solanacearum, was higher in long-term cropping treatments compared with the S-CF treatment. The application of organic fertilizers saw an increase in yield and height (Fig. 1) as well as a decrease in the soil-borne disease compared with the chemical fertilizer treatment.

The poor fertility and strong acidity of the red soil derived from quaternary red clay are also important factors that hindered the development of agricultural production (Liu and He 1991). However, due to the long term annual fertilization of the peanut crop, the soil physicochemical properties including soil $\mathrm{pH}$, organic matter, soil total $\mathrm{N}, \mathrm{P}, \mathrm{K}$ and hydrolysable $\mathrm{N}$, available $\mathrm{P}$, available $\mathrm{K}$ contents increased significantly in L-CF and L-OM, compared to the S-CF treatment in this study (Table 1). The marked enhancement in the soil organic matter content in both L-OM treatment and L-CM treatment may be due to plant growth and the increased carbon inputs from physical components i.e. shoots and roots. Previous study showed that as much as $40 \%$ of a plant's photosynthate can be deposited in the soil as sugars, organic acids, and larger organic compounds (Kumar et al. 2006). Additionally, apart from N, P, K and other nutrients manure is also rich in organic matter that may improve soil structure, aeration, soil moisture-holding capacity (Reeves 1997; Watts et al. 2010). The total contents of these nutrients were higher in the L-OM treatment than in the L-CF treatment, which indicated the L-OM treatment could better promoting the growth of peanuts as observed in increase plant height and kernel yield. Many studies have indicated that these changes in soil physicochemical properties could also lead to significant microbial differences (Marschner et al. 2003, 2004; Saha et al. 2008). Girvan et al. (2003) reported that soil properties could be a dominant factor controlling the bacterial community composition. Soil $\mathrm{pH}$ has also been reported as a predictor of bacterial community structure. Lauber et al. (2009) have demonstrated the overall bacterial community's diversity was correlated with soil $\mathrm{pH}$. 
It's reported that the long-term fertilization not only greatly changed the soil physicochemical properties, but also influenced the bacterial community composition and structure (Esperschütz et al. 2007; Melero et al. 2008; Sarathchandra et al. 2001). Soil microbial communities can greatly influence the productivity and overall quality of the agricultural ecosystem due to roles in nutrient cycling, detoxification processes and soil aggregate stability, among other functions (Naeem and Li 1997; Bell et al. 2005; Cardinale et al. 2006; Costa et al. 2007). The long-term fertilization regimes resulted in the changes of soil bacterial community structure and diversity during the growth stage in 2012, and the overall bacterial community structure of L-OM treatment were significantly different from the L-CF treatment (Figs. 2 and 5). A possible benefit to the application of organic fertilizer is an associated increase in the abundance and activity of soil biota, such as soil microorganisms, protozoans, nematodes, collembolans and earthworms (Cao et al. 2011).

The results of this study showed that long-term fertilizations treatments had led to great changes in bacterial community structure. The most dominant bacterial group in this soil was the Proteobacteria, similar to a report for several soils, which has great importance to global carbon, nitrogen and sulfur cycling (Spain et al. 2009). Actinobacteria was the second most abundant phylum and on average proportion abundance across the treatments was found to be $\mathrm{S}-\mathrm{CF}>\mathrm{L}-\mathrm{OM}>\mathrm{L}-\mathrm{CF}$ (Fig. 2). Previously lower relative abundance of Actinobacteria under long-term chemical fertilizer compared with organic fertilizer has been reported (Chaudhry et al. 2012). Similar to previous study, Acidobacteria, the third most abundant phylum, did not correlate with nutrient level but did correlate to $\mathrm{pH}$. The abundance of Acidobacteria was negatively correlated with $\mathrm{pH}$ and decreased as a percentage of sequences in L-OM treatment compared with the other two treatments. Several studies have reported that most known antibiotics from a bacterial origin, such as streptomycin, oxytetracycline, tetracycline, gentamicin, are produced by members of Actinobacteria. Actinobacteria can survive in the soil environment and are thought to be beneficial in the agricultural soils (Marta et al. 2014). Acidobacteria also display a functional capability and specialize on degradation of plantderived organic matter (Naumoff and Dedysh 2012). Members of Bacteroidetes, which were often involved in the degradation of bio-macromolecules such as proteins, cellulose, chitin, pectin, agar, starch (Hugenholtz et al. 1998), and more recalcitrant compounds (Lipson and Schmidt 2004), increased proportionally in the L-OM treatment. Planctomycetes were positively correlated with soil microbial biomass $\mathrm{C}$ and $\mathrm{N}$, and involved in carbon and nitrogen cycles (Chistoserdova et al. 2004; Justin et al. 2012) but constituted a minor component of the community. Their abundance has previously been reported to be influenced by soil management and compost addition (Buckley et al. 2006). Nitrospirae was also present in minor abundance but increased in all treatments during the peanut plant growth phase. It has been demonstrated that Nitrospirae has a positive effect on promoting plant growth and enhancing the absorption of trace elements from soil to plants (Chen et al. 1981).

Li et al. (2014b) found that the fungal Leptosphaerulina sp., Fusarium sp. seemed to be the main cause for the yield decline and poor growth of monocultured peanut by root rot in the red soil. However, our previous experiment showed that peanut bacterial wilt caused by $R$. solanacearum, a devastating diseases for peanut production, had a ratio of peanut wilt was as higher as $58 \%$ in L-CF treatments (Wang et al. 2011). According to the field pyrosequencing investigation the soil-borne disease Ralstonia sp. occurred in all treatments with its relative abundance under all treatments quickly increasing during the plant growth stage (Fig. 3). This increase may be due to no viable host being present for the pathogen at sowing time, with the increase in population associated with greater plant roots and exudates. The relative abundance of Ralstonia sp. in L-CF treatment was significantly higher than that in LOM in August (Fig. 3). Many studies demonstrated that the organic fertilizer can be used for improving crop production, soil health, nutrient levels, organic matter, plant growth and suppression of disease caused by soilborne plant pathogens (Chaney et al. 1980; Mays and Giordano 1989; Mikhail et al. 2005).

An abundance of beneficial soil organisms could suppress pathogens and diseases, improve nutrient availability, promote plant growth, and thus increased the crop yield ( $\mathrm{Ji}$ et al. 2008; Ramesh et al. 2009; Liu et al. 2012; Yuan et al. 2014). Streptomyces sp. are especially prolific as plant growth promoters and fungal plant pathogen antagonists, improving crop yield by increasing photosynthesis, controlling soil diseases and accelerating decomposition of lignin material in the soil (Oskay 
et al. 2005; Lwin and Ranamukhaarachchi 2006; Hill et al. 2011). Streptomyces sp. increased from $0.11,0.12$, and $0.23 \%$ (April) to $0.45,0.28$, and $0.53 \%$ (August) in S-CF, L-CF and L-OM treatments, respectively (Fig. 4). Additionally, the relative abundances of genera identified as Bacillus sp., Arthrobacter sp. and Sphingomonas sp., are now being used as worldwide bacterial antagonists against $R$. solanacearum (Li et al. 2005; Hu et al. 2007; Huang et al. 2011; Yuan et al. 2014). All of the three genera were increased in L-CF and L-OM treatments (Fig. 4). Interestingly, these genera were always higher in L-OM than in L-CF at the harvest time (Fig. 4). CCA further demonstrated that the beneficial microbial' abundance, such as Arthrobacter, Bacillus and Sphingomonas species, were positively correlated with the soil physicochemical properties, particularly $\mathrm{pH}$ and total and available $\mathrm{P}$ for the L-OM samples while the pathogenic bacterial, $R$. solanacearum, was negatively correlated with them. Similar results are also reported in the literature that the microbial maximal growth activity was observed in the long-term $\mathrm{P}$ fertilized soils (Zheng et al. 2009; Lin et al. 2012). We suspected that the organic fertilizers more effectively increased diversity (Table 2) and changed the community structure (Fig. 5) that may have increased competition between the bacterial community and the $R$. solanacearum pathogen than in the chemical fertilizer. Additionally, organic matter has many benefits for the soil food web as well as physical benefits to soil structure.

\section{Conclusion}

In summary, with the increasing years of continuous peanut monocropping, the peanut yield and height decreased. Soil $\mathrm{pH}$ and the contents of organic matter, $\mathrm{N}, \mathrm{P}$ and $\mathrm{K}$ in the soils increased with the longterm fertilization compared with the 2-year of shortterm chemical fertilization and the total contents of these nutrients were higher in the L-OM treatment than in the L-CF treatment. Pyrosequencing results clearly showed that bacterial community diversity under the long-term monocropping with chemical fertilizer was less than under organic fertilizer treatment during the sampling times. The bacterial pathogen $R$. solanacearum was found to cause peanut wilt disease at the late growing stage that lead to production decrease. The greater population of $R$. solanacearum, in the chemical fertilizer treatment resulted in more severe cropping obstacle, which could explain for yield declines over consecutive peanut monoculturing. The application of organic fertilizer was more beneficial for ameliorating the peanut continuous cropping obstacle than the chemical fertilizer. It may be due to the organic fertilizer has changed the microbial community to increase diversity and beneficial bacteria, which may have increased competition between the bacterial community and the $R$. solanacearum pathogen, as well as improving organic matter which has many benefits for the soil food web as well as physical benefits to soil structure.

Acknowledgments We thank National Natural Science Foundation of China (41471236, 41325003) and Jiangsu Provincial Natural Science Foundation of China (BK2012891) for financial support.

\section{References}

Acosta-Martínez V, Burow G, Zobeck TM, Allen VG (2010) Soil microbial communities and function in alternative systems to continuous cotton. Soil Sci Soc Am J 74:1181-1192

Allen C, Prior P, Hayward AC (2005) Bacterial wilt disease and the Ralstonia solanacearum species complex. American Phytopathological Society (APS Press)

Bell T, Newman JA, Silverman BW, Turner SL, Lilley AK (2005) The contribution of species richness and composition to bacterial services. Nature 436:1157-1160

Buckley DH, Huangyutitham V, Nelson TA, Rumberger A, Thies JE (2006) Diversity of planctomycetes in soil in relation to soil history and environmental heterogeneity. Appl Environ Microbiol 72:4522-4531

Cao ZP, Han XM, Hu C, Chen J, Zhang DP, Yosef S (2011) Changes in the abundance and structure of a soil mite (Acari) community under long-term organic and chemical fertilizer treatments. Appl Soil Ecol 49:131-138

Cardinale BJ, Srivastava DS, Duffy JE, Wright JP, Downing AL, Sankaran M, Jouseau C (2006) Effects of biodiversity on the functioning of trophic groups and ecosystems. Nature 443: 989-992

Chaney RL, Munns JB, Cathey HM (1980) Effectiveness of digested sewage sludge compost in supplying nutrients for soilless potting media. J Am Soc Hortic Sci 150:485-493

Chaudhry V, Rehman A, Mishra A, Chauhan PS, Nautiyal CS (2012) Changes in bacterial community structure of agricultural land due to long-term organic and chemical amendments. Microb Ecol 64:450-460

Chen HG, Li FD, Chen YX (1981) Soil microbiology. Shanghai Science Technology Press, Shanghai (in Chinese) 
Chen ZJ, Sheng XF, He LY, Huang Z, Zhang WH (2013) Effects of root inoculation with bacteria on the growth, Cd uptake and bacterial communities associated with rape grown in Cdcontaminated soil. J Hazard Mater 244:709-717

Chistoserdova L, Jenkins C, Kalyuzhnaya MG, Marx CJ, Lapidus A, Vorholt JA, Staley JT, Lidstrom ME (2004) The enigmatic planctomycetes may hold a key to the origins of methanogenesis and methylotrophy. Mol Biol Evol 21: $1234-1241$

Colwell RK (2009) EstimateS: statistical estimation of species richness and shared species from samples. Version 8.2. User's guide and application published at: http://purl.oclc. org/estimates

Costa AL, Paixão SM, Caçador I, Carolino M (2007) CLPP and EEA profiles of microbial communities in salt marsh sediments. J Soils Sediments 7:418-425

Crecchio C, Curci M, Mininni R, Ricciuti P, Ruggiero P (2001) Short-term effects of municipal solid waste compost amendments on soil carbon and nitrogen content, some enzyme activities and genetic diversity. Biol Fertil Soils 34:311-318

Das R, Kazy SK (2014) Microbial diversity, community composition and metabolic potential in hydrocarbon contaminated oily sludge: prospects for in situ bioremediation. Environ Sci Pollut Res 21:7369-7389

Esperschütz J, Gattinger A, Mäder P, Schloter M, Fliessbach A (2007) Response of soil microbial biomass and community structures to conventional and organic farming systems under identical crop rotations. FEMS Microbiol Ecol 61:26-37

Fierer N (2009) A comprehensive survey of soil acidobacterial diversity using pyrosequencing and clone library analyses. ISME J 3(4):442-453

Freitag TE, Chang L, Clegg CD, Prosser JI (2005) Influence of inorganic nitrogen management regime on the diversity of nitrite-oxidizing bacteria in agricultural grassland soils. Appl Environ Microbiol 71:8323-8334

Girvan MS, Bullimore J, Pretty JN, Osborn AM, Ball AS (2003) Soil type is the primary determinant of the composition of the total and active bacterial communities in arable soils. Appl Environ Microbiol 69:1800-1809

Hill P, Krištůfek V, Dijkhuizen L, Boddy C, Kroetsch D, van-Elsas JD (2011) Land use intensity controls actinobacterial community structure. Microb Ecol 61:286-302

$\mathrm{Hu}$ J, He X, Li D, Liu Q (2007) Progress in research of Sphingomonas. Chin J Appl Environ Biol 13:431

Huang MY, Gu WJ, Zhang FB, Xu PZ, Yang SH, Wang LQ, Xie KZ (2011) Identification and fermentation of antagonistic bacterium against Ralstonia solanacearum. Chin Microbiol 38:214-220

Hugenholtz P, Goebel BM, Pace NR (1998) Impact of cultureindependent studies on the emerging phylogenetic view of bacterial diversity. J Bacteriol 180:4765-4774

Ji XL, Lu GB, Gai YP, Zheng CC, Mu ZM (2008) Biological control against bacterial wilt and colonization of mulberry by an endophytic Bacillus subtilis strain. FEMS Microbiol Ecol 65:565-573

Justin PN, Emily BH, Ma.del Carmen AGC, Frank MH, David AZ, Jacqueline AAP, Richard L, Terry J (2012) Impacts of cropping systems and long-term tillage on soil microbial population levels and community composition in Dryland agricultural setting. ISRN Ecology. doi:10.5402/2012/ 487370
Kong AYY, Scow KM, Córdova-Kreylos AL, Holmes WE, Six J (2011) Microbial community composition and carbon cycling within soil microenvironments of conventional, lowinput, and organic cropping systems. Soil Biol Biochem 43: 20-30

Kumar R, Pandey S, Pandey A (2006) Plant roots and carbon sequestration. Curr Sci 91:885-890

Larkin RP (2003) Characterization of soil microbial communities under different potato cropping systems by microbial population dynamics, substrate utilization, and fatty acid profiles. Soil Biol Biochem 35:1451-1466

Lauber CL, Strickland MS, Bradford MA, Fierer N (2008) The influence of soil properties on the structure of bacterial and fungal communities across land-use types. Soil Biol Biochem 40:2407-2415

Lauber CL, Hamady M, Knight R, Fierer N (2009) Pyrosequencing-based assessment of soil $\mathrm{pH}$ as a predictor of soil bacterial community structure at the continental scale. Appl Environ Microbiol 75:5111-5120

Li YM, Hu JC, Zhang J, Wang SL (2005) Microbial diversity in continuously planted Chinese fir soil. Chin J Appl Ecol 16: $1275-1278$

Li PD, Dai CC, Wang XX, Zhang TL, Chen Y (2012) Variation of soil enzyme activities and microbial community structure in peanut monocropping system in subtropical China. Afr J Agric Res 7:1870-1879

Li XG, Ding CF, Hua K, Zhang TL, Zhang YN, Zhao L, Yang YR, Liu JG, Wang XX (2014a) Soil sickness of peanuts is attributable to modifications in soil microbes induced by peanut root exudates rather than to direct allelopathy. Soil Biol Biochem 78:149-159

Li XG, Ding CF, Zhang TL, Wang XX (2014b) Fungal pathogen accumulation at the expense of plant-beneficial fungi as a consequence of consecutive peanut monoculturing. Soil Biol Biochem 72:11-18

Lian CY, Wang XX, Li YL (2010) Effects of planting peanut and applying urea and organic materials on acidity of red soil. Soils (in Chinese) 42:822-827

Lin XG, Feng YZ, Zhang HY, Chen RR, Wang JH, Zhang JB, Chu HY (2012) Long-term balanced fertilization decreases arbuscular mycorrhizal fungal diversity in an arable soil in north china revealed by 454 pyrosequencing. Environ Sci Technol 46:5764-5771

Lipson DA, Schmidt SK (2004) Seasonal changes in an alpine soil bacterial community in the Colorado Rocky Mountains. Appl Environ Microbiol 70:2867-2879

Liu X, He XY (1991) Progress and achievement in the research on red soil in Jiangxi. Acta Agric Jiangxi (in Chinese) 1:014

Liu JG, Li YB, Jiang GY, Bian XM, Li F, Geng W (2008) Allelopathic effects of cotton in continuous cropping. Allelopathy J 21:299-306

Liu YX, Shi JX, Feng YG, Yang XM, Li X, Shen QR (2012) Tobacco bacterial wilt can be biologically controlled by the application of antagonistic strains in combination with organic fertilizer. Biol Fertil Soils 47:239-248

Lu RK (1999) Analytical methods of soil agricultural chemistry. China Agriculture Science and Technology Press, Beijing (in Chinese)

Lwin M, Ranamukhaarachchi SL (2006) Development of biological control of Ralstonia solanacearum through antagonistic microbial populations. Int J Agric Biol 8(5):657-660 
Mannisto MK, Tiirola M, Haggblom MM (2007) Bacterial communities in Arctic fjelds of Finnish Lapland are stable but highly pH-dependent. FEMS Microbiol Ecol 59:452-465

Margulies D, Melman G, Shanzer A (2005) Fluorescein as a model molecular calculator with reset capability. Nat Mater 4:768-771

Marschner P, Kandeler E, Marschner B (2003) Structure and function of the soil microbial community in a long-term fertilizer experiment. Soil Biol Biochem 35:453-461

Marschner P, Crowley D, Yang CH (2004) Development of specific rhizosphere bacterial communities in relation to plant species, nutrition and soil type. Plant Soil 261:199-208

Marta AP, Juan DA, Claudia SB, María JA (2014) 11 - role of Actinobacteria in bioremediation. Microb Biodegrad Biorem 2014:269-286

Mays DA, Giordano DM (1989) Land spreading municipal waste compost. Biocycle 30:37-39

McAndrew DW, Malhi SS (1992) Long-term N fertilization of a solonetzic soil: effects on chemical and biological properties. Soil Biol Biochem 24:619-623

Melero S, Madejon E, Herencia JF, Ruiz JC (2008) Effect of implementing organic farming on chemical and biochemical properties of an irrigated loam soil. Agron J 100:136-144

Mikhail MS, Sabet KK, Mohamed ME, Kenawy MH, Kasem KK (2005) Effect of compost and macronutrients on some cotton seedling diseases. Egypt J Phytopathol 33:41-52

Moreira D (1998) Efficient removal of PCR inhibitors using agarose-embedded DNA preparations. Nucleic Acids Res 26:3309-3310

Naeem S, Li S (1997) Biodiversity enhances ecosystem reliability. Nature 390:507-509

Naumoff DG, Dedysh SN (2012) Lateral gene transfer between the Bacteroidetes and Acidobacteria: the case of $\alpha-\mathrm{L}-$ rhamnosidases. FEBS Lett 586:3843-3851

Nie LX, Peng SB, Bouman BAM, Huang J, Cui K, Vispera RM, Xiang J (2008) Alleviating soil sickness caused by aerobic monocropping: responses of aerobic rice to nutrient supply. Field Crop Res 107:129-136

Nishio M, Kusano S (1973) Fungi associated with roots of continuously cropped upland rice. Soil Sci Plant Nutr 19:205217

Oskay AM, Usame T, Cem A (2005) Antibacterial activity of some actinomycetes isolated from farming soils of Turkey. Afr J Biotechnol 3:441-446

Peacock AD, Mullen MD, Ringelberg DB, Tyler DD, Hedrick DB, Gale PM, White DC (2001) Soil microbial community responses to dairy manure or ammonium nitrate applications. Soil Biol Biochem 33:1011-1019

Ramesh R, Joshi A, Ghanekar M (2009) Pseudomonads: major antagonistic endophytic bacteria to suppress bacterial wilt pathogen, Ralstonia solanacearum in the egg plant (Solanum melongena L.). World J Microbiol Biotechnol 25: $47-55$
Reeves DW (1997) The role of soil organic matter in maintaining soil quality in continuous cropping systems. Soil Tillage Res 43:131-167

Ribeiro H, Mucha AP, Marisa R, Almeida C, Bordalo AA (2013) Bacterial community response to petroleum contamination and nutrient addition in sediments from a temperate salt marsh. Sci Total Environ 458:568-576

Saha S, Prakash V, Kundu S, Kumar N, Minna BL (2008) Soil enzymatic activity as affected by long term application of farm yard manure and mineral fertilizer under a rainfed soybean-wheat system in N-W Himalaya. Eur J Soil Biol 44:309-315

Sarathchandra SU, Ghani A, Yeates GW, Burch G, Cox NR (2001) Effect of nitrogen and phosphate fertilisers on microbial and nematode diversity in pasture soils. Soil Biol Biochem 33: 953-964

Schloss PD, Gevers D, Westcott SL (2011) Reducing the effects of PCR amplification and sequencing artifacts on 16S rRNAbased studies. PLoS One 6, e27310

Spain AM, Lee RK, Elshahed MS (2009) Abundance, composition, diversity and novelty of soil Proteobacteria. ISME J 3: 992-1000

Wang MZ, Chen XN (2005) Obstacle and countermeasure of sustainable high yield for peanut in low-hilly red soil region. J Peanut Sci (in Chinese) 34:17-22

Wang XB, Luo YM, Li ZG, Liu WX, He YQ (2011) Effects of long-term stationary fertilization experiment on incidence of soil-borne diseases and biological characteristics of peanut in continuous monocropping system in red soil area. Acta Pedol Sin 48:725-730

Watts DB, Torbert HA, Feng Y, Prior SA (2010) Soil microbial community dynamics as influenced by composted dairy manure, soil properties, and landscape position. Soil Sci 175: 474-486

Wu M, Qin H, Chen Z, Wu J, Wei W (2011) Effect of long-term fertilization on bacterial composition in rice paddy soil. Biol Fertil Soils 47:397-405

Xu K, Tang Y, Ren C, Zhao K, Sun Y (2013) Diversity and abundance of $n$-alkane-degrading bacteria in the nearsurface soils of a Chinese onshore oil and gas field. Biogeosciences 10:2041-2048

Yuan SF, Wang LL, Wu K, Shi JX, Wang MS, Yang XM, Shen QR, Shen B (2014) Evaluation of Bacillus-fortified organic fertilizer for controlling tobacco bacterial wilt in greenhouse and field experiments. Appl Soil Ecol 75:86-94

Zheng SX, Hu JL, Chen K, Yao J, Yu ZN, Lin XG (2009) Soil microbial activity measured by microcalorimetry in response to long-term fertilization regimes and available phosphorous on heat evolution. Soil Biol Biochem 4:2094-2099

Zhou XG, Gao DM, JLiu J, Qiao PL, Zhou XL, Lu HB, Wu X, Liu D, Jin X, Wu FZ (2014) Changes in rhizosphere soil microbial communities in a continuously monocropped cucumber (Cucumis sativus L.) system. Eur J Soil Biol 60:1-8 